\title{
CORRESPONDENCE
}

\section{The Rhiwnant Inlier, Powys, Mid-Wales}

SI R - Recent work on the Rhiwnant Inlier has resulted in several modifications to the previous map and has demonstrated that the cleavage is commonly not axial-planar to the major fold. Additionally, new data on sediment thickness and facies have been collected.

The inlier is situated $11 \mathrm{~km}$ southwest of Rhayader and its axis lies about $5 \mathrm{~km}$ northwest (i.e. across strike) of the axis of the complex anticlinorium which comprises the Towy anticline (Jones, 1912; Fig. 1 inset). The inlier is of importance since, in conjunction with adjacent exposures in the Towy anticline (James, 1983b), it affords exposure of the maximal lateral extent of the slope base facies of uppermost Ordovician strata across palaeostrike. Further northwest, time-equivalent basinal facies are next exposed about $25 \mathrm{~km}$ away at Plynlimon (James, 1983a).

The inlier was first recognized, and named, by K. A. Davies $(1926$, p. 438$)$ in the course of his work on the stratigraphy of the basinal sediments west of the Towy anticline (Davies, 1926, 1928, 1933). The only published map was given by Davies \& Platt (1933, pl. XIX) and it appears, without change, in the recent compilation of maps in the Central Wales Mining Area (Ball \& Nutt, 1976). At the time of Davies' work the base of the Silurian was taken at the base of the $G$. persculptus Zone; however this has recently been revised to the base of the $P$. acuminatus Zone (Cocks et al. 1984) and this usage is basically followed herein: thus the Cerriggwynion Grits are taken to be entirely of Ordovician age. These Grits were studied sedimentologically by Kelling \& Woollands (1969) and have not been restudied in the present work.

The writers' map is given in Figure 1. It covers the majority of the inlier but omits the extremely poorly exposed southwestern portion towards Nant-y-Rhestr where mapping is highly subjective. The thin layer (approx. $15 \mathrm{~m}$ ) of presumed persculptus Zone mudstones which underlies the Cerriggwynion Grits (cf. Kelling \& Woollands, 1969, p. 259) is not separately distinguished.

(1) The map documents the asymmetry of the anticline and local inversion of the eastern limbs of folds not apparent on the previous map which does not give dip data. Associated with the asymmetric fold style are several high angle reverse faults (cf. Bassett, 1969, p. 91; James, 1983b, figs. 2 and 3) similar to those within the Towy anticline. The map also demonstrates previously unrecognized structural complexity in the Cerriggwynion Grits northeast of Llyn Carw and Craig Llanerch-y-cawr (GR SN 895612).

(2) Several normal and probable tear faults are not shown by Davies \& Platt. In particular that trending NNW in the lower portion of Nant Paradwys (GR SN 892608) has a convincing sinistral offset of about $60 \mathrm{~m}$ as revealed by displacement of near-vertical arenites. Nearby faults of similar trend may also have sinistral movements on them.

(3) The map illustrates major revision and extension of the outcrop of the lowermost Ordovician turbidite arenites, here termed the Craig Rhiwnant Grits. Davies \& Platt do not show the outcrops of these on the northwest limb of the fold around Nant Carw where the outcrop pattern is influenced by minor folding and faulting. Most importantly their map is incorrect in showing continuity of arenite outcrop between the waterfall in the Rhiwnant stream (GR SN 8848 6082) and the small area of outcrop in Afon Claerwen (GR SN 8915 6190). This latter outcrop is fault bounded to the west and exposes only $8 \mathrm{~m}$ of arenites. These appear to lie almost $400 \mathrm{~m}$ below the base of the persculptus Zone on somewhat sparse control of the plunge of the fold. However thickening of the intervening mudstones in the core of the fold is likely and the true thickness of these mudstones is about $320 \mathrm{~m}$ as determined on the fold limbs.

(4) There is an appreciable area of outcrop of strata lying below the Craig Rhiwnant Grits around the confluence of Rhiwnant and Nant Carw. It is estimated that this sequence is about $120 \mathrm{~m}$ thick; it is well exposed and almost entirely mudstone (a thin horizon of balled-up arenites occurs about $25 \mathrm{~m}$ below the Grits in Nant Carw). It is not clear whether this sequence is erosively overlain by the arenites which vary in thickness from $31 \mathrm{~m}$ around GR SN 885608 to about $65 \mathrm{~m}$ around GR SN 870598 (respectively illustrated as a and b in Figure 1). If the contact is not markedly erosive the total thickness of pre-persculptus Zone sediments exposed in the Rhiwnant inlier would be about $500 \mathrm{~m}$.

The major folds within the Rhiwnant anticline trend about $045^{\circ}$ to $050^{\circ}$. Minor folds are not well expressed individually but appear to do likewise. In local domains the cleavage strike lies within $5^{\circ}$ of the strike of the axial plane and is essentially axial-planar. However, local divergence of $10-15^{\circ}$ and, rarely, $20-25^{\circ}$ between cleavage and the major fold-axial planes may be observed in most areas of the structure and the cleavage divergence is consistently anticlockwise (sinistral) with respect to the folds. At GR SN 89056190 adjacent to the axial trace of the major fold, cleavage strikes at $025^{\circ}$ and along the track around GR SN 886622 is well displayed striking at $030-035^{\circ}$. At GR SN 89856153 cleavage strikes at $030^{\circ}$ adjacent to minor folds in the Cerriggwynion Grits near the bridge to the east which have axial planes striking at $045^{\circ}$. In Nant Carw around GR SN 87356065 a complex cleavage with strikes varying between $020^{\circ}$ and $050^{\circ}$ in local domains separated by $0.05-0.1 \mathrm{~m}$ transition zones may be observed. The single (albeit variably oriented) cleavage does not fan across the inlier and dips between $55^{\circ}$ and $85^{\circ}$ to the northwest with values of $65-70^{\circ}$ being very common. The anticlockwise transection of the major folds by the cleavage is in marked contrast to areas to the northwest and southwest (Woodcock, 1984, fig. 3) where the sense is clockwise, as indeed it is also (very strongly) in the core of the Towy fold just north of the volcanic outcrop at GR SN 884516 (personal observations).

The Craig Rhiwnant Grits are considered to be the basinward equivalent of massive arenites exposed to the east in the Towy anticline (James, 1983 b, fig. 1). At Rhiwnant the arenites contain fewer pebbly beds and more thinner and finer beds than in the Towy anticline. Two representatives logged sections are illustrated in Figure 1 using the same facies terminology as that used further west in the Plynlimon inlier (James, 1983a, table I). Two further sections have been measured although not as well exposed as those illustrated. Both are in the centre of the inlier; on the Rhiwnant stream above GR SN 878604 where the thickness is $45 \mathrm{~m}$ and on Nant Carw above GR SN 872608 where the thickness is $48 \mathrm{~m}$ including a $4 \mathrm{~m}$ mudstone band which forms a waterfall. There is thus a progressive thinning of the Craig 

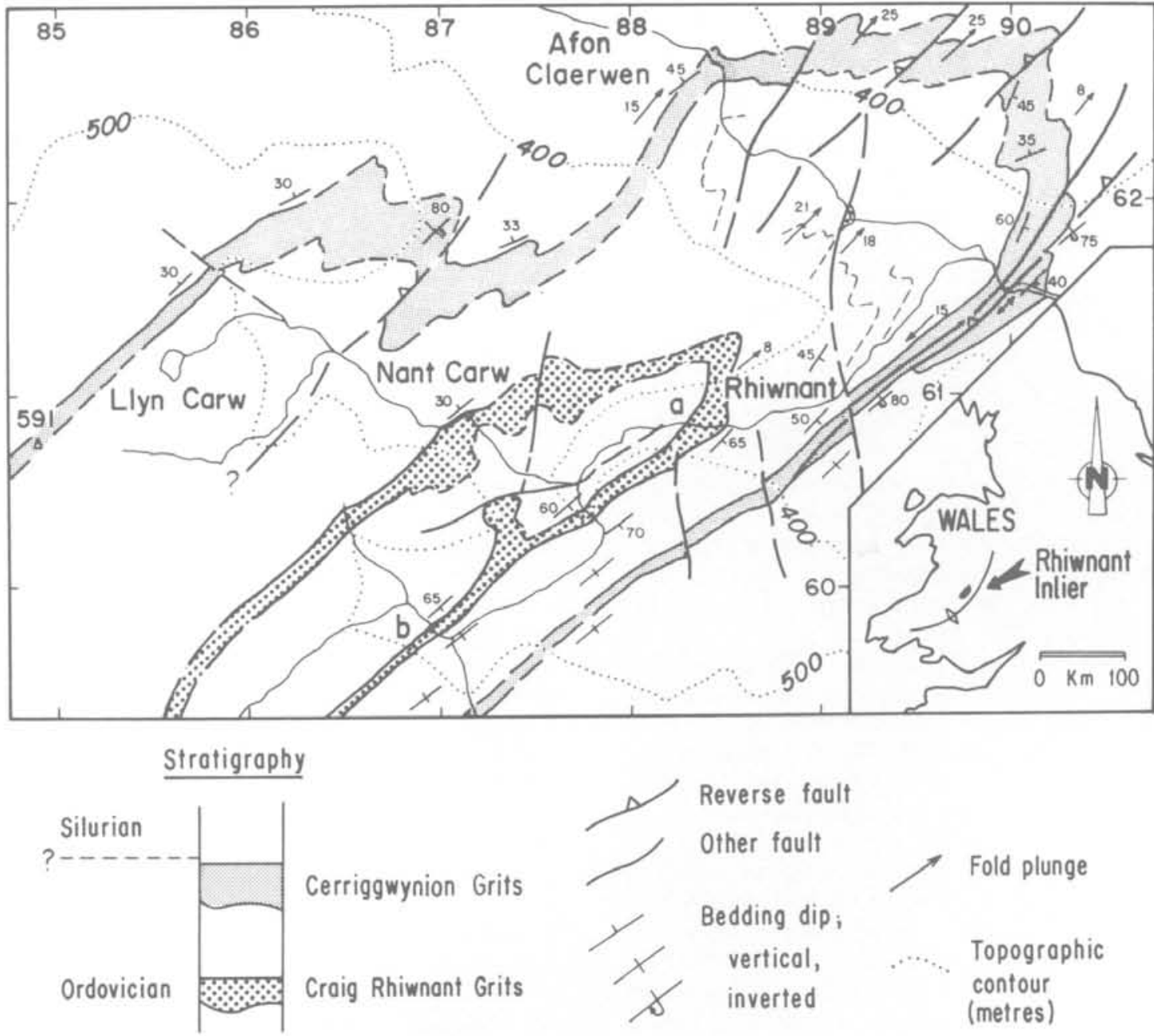

(a)

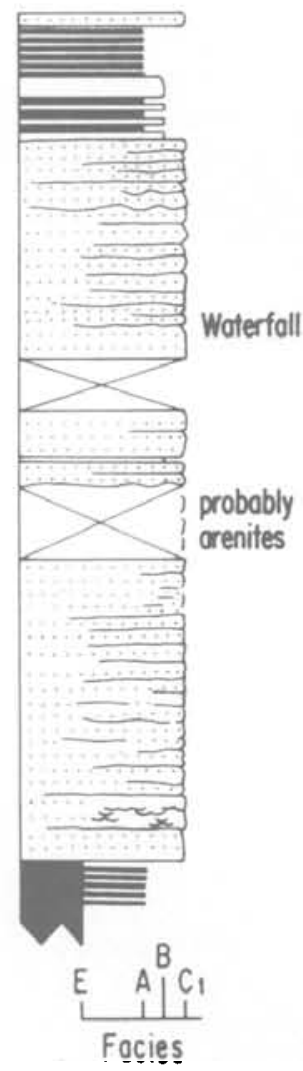

(b)

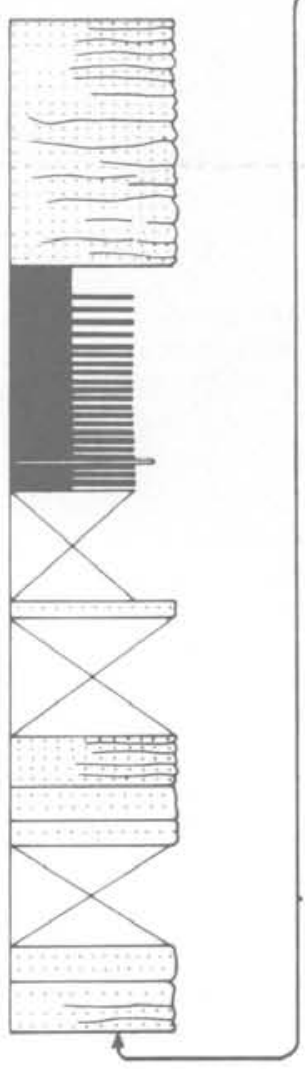

nearby hillside exposures suggest probably largely mudstone

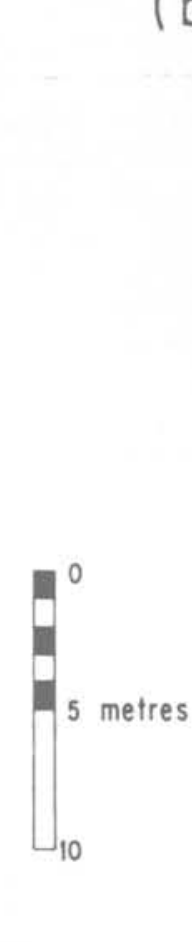

Figure 1. Geological map of the northeastern Rhiwnant Inlier and sedimentological logs of the Craig Rhiwnant Grits. The logs (a) and (b) are of sections located respectively at GR SN 885608 and GR SN 870598 and are shown on the map by the letters $a$ and $b$. 
Rhiwnant Grits from southwest to northeast across the inlier. The Grits are dominantly composed of massive, frequently amalgamated, arenites individually about 0.5-1.5 m thick (facies $C_{1}$ ). The arenites display poor normal grading and frequent absence of Bouma divisions $c, d$ and $e$. Channelling at outcrop scale appears to be absent. Sole marks are very rare, most beds having planar bases. Mudstones interbedded with ripple-laminated siltstones (facies A) and rare graded arenites $0.1-0.25 \mathrm{~m}$ thick (facies B) also form thick packets and these do not appear to be laterally continuous between the illustrated measured sections $1.8 \mathrm{~km}$ apart. A likely environment of deposition would be the lower portion of the middle fan. Transport direction as revealed almost entirely by cross lamination is principally northwestward but locally also northeastward, in one case on sole mark evidence (James \& James, 1969, p. 570). This pattern is consistent with a more basinward situation than that to the east with lower gradients allowing greater spreading of turbidity current flow. The presumed hemi-pelagic silty mudstones of facies $\mathrm{E}$ are very monotonous and slump structures are not obvious therein; this is in contrast to the common occurrence of slump structures in equivalent mudstones in the Towy anticline to the east which were deposited closer to the marginal slope of the basin (James, 1983b).

While the new sedimentological results clearly fit easily within the regional picture, the significance of the structural results will need appraisal within a larger regional data base than currently available. Clockwise transection of folds by cleavage occurs $15 \mathrm{~km}$ northwest of Rhiwnant in the upper Ystwyth valley (personal observation) and the intervening ground is currently under study by the writer.

\section{References}

Ball, T. K. \& NutT, M. J. C. 1976. Preliminary mineral reconnaisance of Central Wales. Report of the Institute of Geological Sciences, no. 75/14, 12 pp. (with mineral reconnaisance map published in 1974).

BASSETT, D. A. 1969. Some of the major structures of early Palaeozoic age in Wales and the Welsh Borderland: an historical essay. In The Precambrian and Lower Palaeozoic Rocks of Wales (ed. A. Wood), pp. 67-115. Cardiff: University of Wales Press.

Cocks, L. R. M., Woodcock, N. H., LANE,P. D., Rickards, R. B. \& TEMPLE, J. T. 1984. The Llandovery Series of the type area. Bulletin of the British Museum of Natural History (Geology) 38 (3), 131-82.

DAvies, K. A. 1926. The geology of the country between Drygarn and Abergwesyn, Breconshire. Quarterly Journal of the Geological Society of London 82, 436-64.

DAvies, K. A. 1928. Contributions to the geology of Central Wales. II. The geology of the country between Rhayader(Radnorshire)and A bergwesyn(Breconshire). Proceedings of the Geologists Association 39, 157-68.

Davies, K. A. 1933. The geology of the country between Abergwesyn (Breconshire) and Pumpsaint (Carmarthenshire). Quarterly Journal of the Geological Society of London 89, 172-201.

Davies, K. A. \& PlatT, J. I. 1933. The conglomerates and grits of the Bala and Valentian rocks of the district between Rhayader (Radnorshire) and Llansawel (Carmarthenshire). Quarterly Journal of the Geological Society of London 89, 202-20.

JAMES, D. M. D. 1983a. Sedimentation of deep-water slope-base and inner fan deposits-the Drosgol Formation (Ashgill), West Central Wales. Sedimentary Geology 34, 21-40.

JAMES, D. M. D. $1983 b$. Observations and speculations on the northeast Towy 'axis', mid-Wales. Geological Journal 18, 283-96.

JAMES, D. M. D. \& JAMES, J. 1969. The influence of deep fractures on some areas of Ashgillian-Llandoverian sedimentation in Wales. Geological Magazine 106, 562-82.

JONES, O. T. 1912. The geological structure of Central Wales and the adjoining regions. Quarterly Journal of the Geological Society of London 68, 328-44.

Kelling, G. \& WoOllands, M. A. 1969. The stratigraphy and sedimentation of the Llandoverian rocks of the Rhayader district. In The Precambrian and Lower Palaeozoic Rocks of Wales (ed. A. Wood), pp. 225-82. Cardiff: University of Wales Press.

WoodCock, N. H. 1984. Early Palaeozoic sedimentation and tectonics in Wales. Proceedings of the Geologists' Association 95, 323-35.

D. M. D. JAMES

c/o A/S Norske Shell

P.O. Box 40

$\mathrm{N}-4056$ Tananger

Norway

25 November 1985 